\title{
STUDI TINGKAT PENDAPATAN PELAKU UTAMA PERIKANAN KERAMBA JARING APUNG (KJA) DI DAM BETUK KECAMATAN TABIR LINTAS KABUPATEN MERANGIN
}

\author{
Noven Meristu Wijaya *, Djunaidi** dan Rini Hertati** \\ * Alumnus Program Studi Pemanfaatan Sumberdaya Perikanan Fakultas Perikanan \\ ** Dosen Program Studi Pemanfaatan Sumberdaya Perikanan Fakultas Perikanan
}

\begin{abstract}
ABSTRAK
Dam betuk merupakan salah satu wilayah perairan yang memiliki peranan penting didalam sektor pertanian maupun perikanan di Kecamatan Tabir Lintas. Dam betuk merupakan bendungan/waduk yang pada awalnya digunakan untuk kegiatan pertanian yang di bangun pada tahun 1981. Namun seiring berjalannya waktu akhirnya Dam betuk dimanfaatkan untuk kegitan perikanan yaitu berupa keramba jaring apung (KJA).

Tujuan penelitian adalah mengetahui tingkat pendapatan pembudidaya ikan keramba jaring apung (KJA) di Dam Betuk Kecamatan Tabir Lintas Kabupaten Merangin. Analisis yang digunakan adalah dengan analisis NPV,B/C, IRR dan surplus produsen.

Metode penelitian yang digunakan dalam penelitian ini adalah metode survey dan wawancara langsung kelokasi penelitian, serta pengambilan sampel dengan metode purposive sampling.

Hasil analisis usaha Usaha keramba jaring apung (KJA) di Dam Betuk merupakan usaha yang layak untuk diusahakan setelah dilakukan analisis biaya dan manfaat terhadap usaha tersebut dengan nilai NPV sebesar Rp 10.936.524, nilai B/C rasio sebesar 2,24, nilai IRR sebesar 31,69 \% , BEP sebesar Rp. 195.757.600 dengan pendapatan persiklus Rp. 2.984.020.
\end{abstract}

Kata kunci : Keramba Jaring Apung (KJA), analisa usaha, tingkat pendapatan 
SEMAH : Journal Pengelolaan Sumberdaya Perairan VOL. 2 No. 3

Desember 2018

\section{Pendahuluan}

Luas perairan umum di Kabupaten Merangin seluas $5.520 \mathrm{Ha}$ yang terdiri dari perairan rawa, danau, dam dan sungai. Dam betuk merupakan salah satu wilayah perairan yang memiliki peranan penting didalam sektor pertanian maupun perikanan di Kecamatan Tabir Lintas. Dam betuk merupakan bendungan/waduk yang pada awalnya digunakan untuk kegiatan pertanian. Berdasarkan data dari Badan Pelaksana Penyuluh Pertanian Perikanan dan Kehutanan Kabupaten Merangin tahun 2016 terdapat sebanyak 254 unit Keramba Jaring Apung (KJA) dengan total produksi mencapai $65.350 \mathrm{~kg}$.

Aspek sosial ekonomi mempunyai dampak positif terhadap pembudidaya ikan keramba jaring apung (KJA) berupa peningkatan perekonomian serta aktifitas yang nerhubungan dengan budidaya ikan keramba jaring apung (KJA). Berdasarkan hal tersebut diatas, perlu dilakukan penelitian tentang Studi Tingkat Pendapatan Pelaku Utama Perikanan Keramba Jaring Apung (KJA) di Dam Betuk Kecamatan Tabir Lintas Kabupaten Merangin.

\section{Metode Penelitian}

Penelitian ini dilaksanakan pada bulan Maret sampai Mei 2018. Yang bertempat di Dam Betuk Desa Tambang Baru, Kecamatan Tabir Lintas, Kabupaten Merangin.

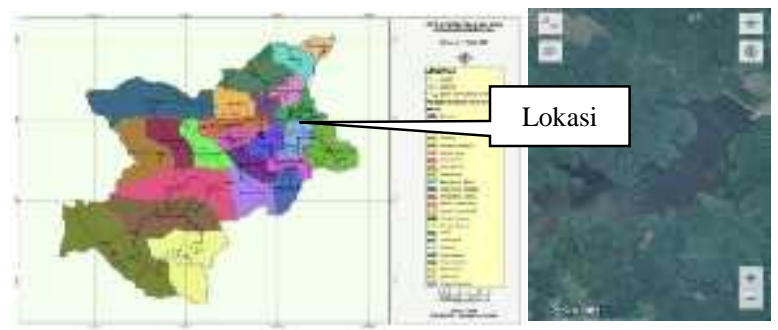

Gambar 1. Lokasi Penelitian
http://ojs.umb-bungo.ac.id/index.php/SEMAHJPSP

ISSN : 2580-0736

Metode penelitian yang digunakan dalam penelitian ini adalah metode survey dan wawancara langsung kelokasi penelitian, di ikuti dengan pengambilan data. Adapun data yang di perlukan dalam penelitian ini adalah data primer dan data sekunder. Dimana data primer adalah data yang diperoleh dari lokasi penelitian, dari hasil wawancara dengan responden yang di pandu dengan daftar pertanyaan (quisioner) yang telah dipersiapkan terlebih dahulu. Sedangkan data sekunder adalah data yang diperoleh dalam bentuk sistematis, yang sudah diolah dan dipublikasikan. Data ini berbentuk buku-buku laporan dan bahan dokumenter lainnya.

Pengambilan sampel pada penelitian ini adalah penduduk yang melakukan budidaya sistem Keramba Jaring Apung (KJA) yang terletak di Desa Tambang Baru. Dimana secara geografis Desa Tambang Baru terletak pada titik koordinat $1^{\circ} 55.807^{\prime}$ LS dan berada pada $102^{\circ} 17.112^{\prime}$ BT.

Pada penelitian ini setiap penduduk yang terlibat dalam kegiatan budidaya sistem keramba jaring apung secara swadaya memiliki kesempatan yang sama untuk terpilih menjadi sampel. Adapun jumlah sampel pada penelitian ini adalah sebanyak 15 orang dengan jumlah keramba sebanyak 41 unit.

Pengambilan sampel dalam penelitian ini dilakukan dengan menggunakan metode sensus. Menurut Subana dan Sudrajad (2001), sensus adalah pengambilan data dari populasi dengan cara mengambil seluruh anggota populasi untuk diambil datanya.

Sistem cara kerja dalam melakukan penelitian:

1.Memberikan selebaran quisioner kepada pembudidaya (sampel), serta melakukan wawancara yang dimaksudkan untuk memperoleh data-data yang diperlukan dalam penyusunan skripsi. 
SEMAH : Journal Pengelolaan Sumberdaya Perairan VOL. 2 No. 3

Desember 2018

2.Mengambil kembali selebaran quisioner yang telah diberikan kepada pembudidaya (sampel).

3.Melakukan analisis data yang telah dikumpulkan.

Analisis yang digunakan dalam penelitian ini ada dua, yaitu analisis deskriftif kondisi umum wilayah penelitian serta analisis usaha kegiatan usaha budidaya Keramba Jaring Apung (KJA)

Analisis deskriftif dilakukan untuk mengetahui kondisi atau gambaran umum, lokasi penelitian, sosial ekonomi dan budaya pembudidaya ikan keramba jaring apung (KJA) yang diperoleh melalui pengamatan lapangan melalui wawancara maupun data sekunder yang mendukung kegiatan penelitian.

Analisa usaha ini digunakan untuk mengetahui komponen-komponen input dan output yang terlibat di dalam kegiatan budidaya ikan keramba jaring apung serta besarnya keuntungan yang diperoleh dari usaha yang dilakukan. Dimana konsep pendapatan dapat dirumuskan sebagai berikut (Sudrajad 2009 dalam Rini, H,,2011)

$a=\mathrm{Py} Y-\sum_{i=1}^{n} \mathrm{PxIX}$

Untuk menunjang penentuan prospek pengembangan budidaya ikan Keramba jaring Apung (KJA) dimasa mendatang, dapat digunakan beberpa indikator. Indikator yang biasa digunakan untuk membandingkan manfaat biaya adalah sebagai berikut :

\section{Net Present Value ( NPV)}

Adalah nilai kini dari keuntungan bersih yang akan diperoleh pada masa yang akan datang, dengan menghitung selisih anatara
http://ojs.umb-bungo.ac.id/index.php/SEMAHJPSP

ISSN : 2580-0736

manfaat dan biaya kini, dimana rumus NPV adalah sebagai berikut :

$\mathrm{NPV}=\frac{b t-c t}{I(1+i)^{4}}-K U$

\section{Net Benefit Cost Ratio (Net B/C)}

Merupakan perbandingan antara jumlah nilai kini (present value total) dari keuntungan bersih pada tahun-tahun dimana keuntungan bersih bernilai positif dengan keuntungan bersih bernilai negatif, adapu rumusnya adalah sebagai berikut :

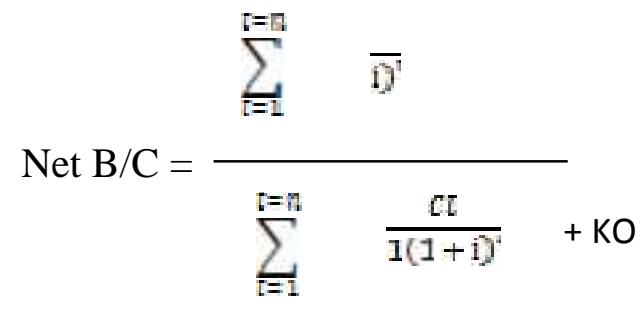

\section{Internal Rate of Return (IRR)}

Adalah tingkat diskonto dimana nilai kini dari biaya total sama dengan nilai kini dari penerimaan total, dengan rumus :

(PVP)

$$
\mathrm{IRR}=\mathrm{i} 1+\left[\frac{}{(\mathrm{PVP})-(\mathrm{PVN})} \mathrm{x}(\mathrm{i} 2-\mathrm{i} 1)\right]
$$

\section{Break Event Point (BEP)}

Hansen dan Mowen (2006) dalam Christine. P (2013) menyatakan break even point adalah titik dimana total pendapatan sama dengan total biaya, titik dimana laba sama dengan nol. Adapun rumus menjcari BEP dalam rupiah adalah sebagai berikut.

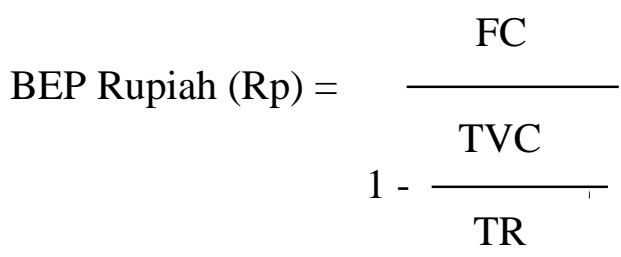


SEMAH : Journal Pengelolaan Sumberdaya Perairan VOL. 2 No. 3

Desember 2018

\section{Hasil dan Pembahasan}

Kabupaten Merangin adalah salah satu Kabupaten yang berada di Provinsi Jambi, dengan ibu kotanya Bangko. Kabupaten Merangin terbentuk dari pemekaran Kabupaten Sarolangun Bangko. Kabupaten Merangin berbatasan dengan beberapa wilayah, meliputi :

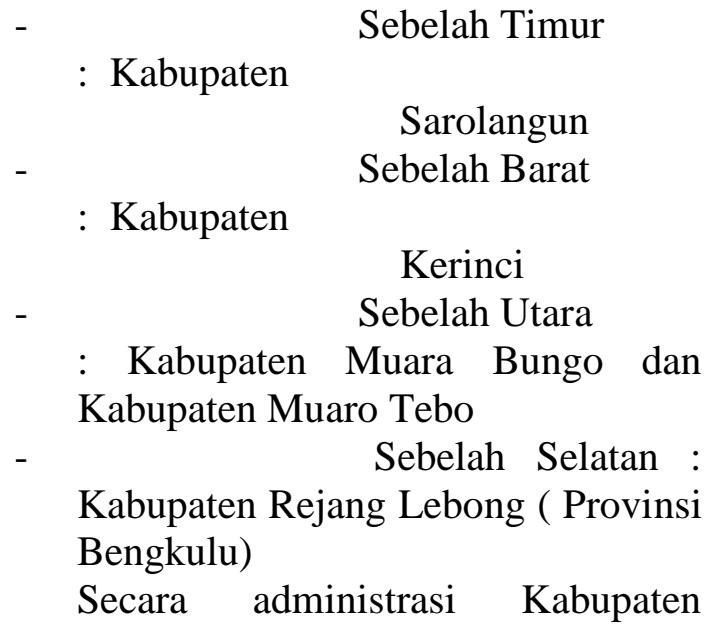
Merangin terdiri dari 24 Kecamatan yang terdiri dari 10 kelurahan dan 203 desa.

Wilayah Kabupaten Merangin secara umum di bagi dalam 3 (tiga) bagian, yaitu dataran rendah, dataran sedang, dan dataran tinggi. Ketinggian berkisar antara $10-1.206$ $\mathrm{m}$ dpl dengan bentang alam rata-rata bergelombang. Pada dataran rendah terletak pada ketinggian 0 - $100 \mathrm{~m}$ dpl dengan luas $42,77 \%$ dari luas Kabupaten, dataran sedang 100 - $500 \mathrm{~m}$ dpl dengan luas 32,53 $\%$ serta dataran tinggi diatas $500 \mathrm{~m} \mathrm{dpl}$ dengan luas $14,5 \%$.

Kabupaten Merangin yang mempunyai beberapa daerah perairaan yang dapat digunakan untuk kegiatan budidaya perikanan, mengingat Kabupaten Merangin terdapat beberapa sungai, rawa dan waduk/ bendungan. Dimana salah satu potensi yang dikembangkan adalah Keramba Jaring Apung (KJA) yang terdapat di Dam Betuk Kecamatan Tabir Lintas yang telah dimanfaatkan untuk kegiatan budidaya ikan sistem Keramba Jaring Apung (KJA) semenjak tahun 1998 hingga saat ini. Berdasarkan data dari Dinas Perikanan Kabupaten Merangin tahun 2015 terdapat sebanyak 254 unit Keramba Jaring Apung (KJA) yang terdiri dari 180 unit keramba bantuan dari Pemerintah dan 74 unit milik pribadi. Keramba yang digunkan adalah berukuran 4x6 meter serta kedalaman keramba 1,5 meter.

Pada kegiatan penelitian ini responden hanya ada satu kelompok saja, yaitu pembudidaya Keramba Jaring Apung (KJA) milik pribadi. Hal ini dikarenakan di Dam Betuk terdapat pembudidaya yang mendapatkan bantuan dari pemerintah, dalam hal ini Dinas Perikanan Kabupaten Merangin. Sedangkan jumlah responden pada penelitian ini adalah sebanyak 15 orang responden. Karakteristik pembudidaya ikan Keramba Jaring Apung (KJA) Dam Betuk dapat dlihat pada Tabel 1. berikut ini :

Tabel 1. Karakteristik pembudidaya ikan Keramba Jaring Apung (KJA) Dam Betuk

\begin{tabular}{llll}
\hline $\begin{array}{l}\text { Karakteristi } \\
\text { k Petani }\end{array}$ & Kategori & $\begin{array}{l}\text { Jum } \\
\text { lah }\end{array}$ & $\begin{array}{l}\text { Prensent } \\
\text { ase (\%) }\end{array}$ \\
\hline Usian & $28-35$ & 4 & 26,67 \\
& tahun & 5 & 33,33 \\
& $36-40$ & 6 & 40 \\
& tahun & $\mathbf{1 5}$ & $\mathbf{1 0 0} \%$ \\
& $41-45$ & & \\
& tahun & & \\
Pendidikan & Jumlah & & \\
& SD & 3 & 20 \\
& SMP & 6 & 40 \\
& SMA & 4 & 26,67 \\
& PT & 2 & 13,33 \\
& Jumlah & $\mathbf{1 5}$ & $\mathbf{1 0 0} \%$ \\
\hline
\end{tabular}

Sumber : Data primer 2018

Dari tabel diatas dapat dilihat usia pembudidaya Keramba Jaring Apung (KJA) 
SEMAH : Journal Pengelolaan Sumberdaya Perairan VOL. 2 No. 3

Desember 2018

di Dam Betuk berikisar antara 28 - 45 tahun. Dimana pada usia 41 - 45 tahun merupakan yang terbanyak (40\%), usia $36-$ 40 sebanyak 33,33\% dan yang terakhir yaitu usia 28 - 35 sebanyak 26,67 \%. Dengan demikian berdasarkan usia pelaku utama perikanan Keramba Jaring Apung (KJA) Dam Betuk berada pada golongan usia produktif. Di Indonesia umumnya usia kerja produktif yaitu berada pada kisaran 15 - 64 tahun. Majid (2008) dalam Rini, H (2011).

Sedangkan untuk tingkat pendidikan responden/ pelaku utama perikanan Keramba Jaring Apung (KJA) yang menamatkan SD sebanyak 3 orang (20\%), tingkat pendidikan SMP sebanyak 6 orang (40\%), tingkat pendidikan SMA sebanyak 4 orang $(26,67 \%)$, serta tingkat pendidikan Perguruan Tinggi sebanyak 2 orang $(13,33 \%)$. jika dilihat dari pemaparan diatas tingkat pendidikan formal pelaku utama perikanan Keramba Jaring Apung (KJA) Dam Betuk, sudah dikatakan cukup baik, hal ini dikarenakan dari jumlah responden yang ada hanya ada 3 orng saja yang berpendidikan sekolah dasar (SD).

Sedangkan jumlah anggota keluarga pembudidaya ikan Keramba Jaring Apung (KJA) Dam batuk tergolong keluarga kecil, dimana jumlah anggota keluarga 4 orang atau kurang yaitu sebesar $80 \%$ sedangkan jumlah anggota keluarga 5-6 orang sebanyak $20 \%$ dan jumlah anggota keluarga 7 orang adalah 0 \%. Dimana menurut Menurut Munir (1986), Jika jumlah anak dalam keluarga itu besar, maka biaya dan waktu alokasi untuk anak akan besar pula dan hal tersebut dapat membebani orang tuanya. Dilihat dari segi ekonomi yang menjadi sebab utama tinggi rendahnya fertilitas adalah beban ekonomi keluarga.

\section{1. $\quad$ Net Persent Value (NPV)}

Dari hasil penelitian yang telah dilakukan, maka diperoleh nilai NPV positif, dengan
http://ojs.umb-bungo.ac.id/index.php/SEMAHJPSP

ISSN : 2580-0736

nilai NPV selama 10 tahun adalah sebesar RP. 10.936.524 pada tingkat suku bunga $5,75 \%$. Perhitungan nilai NPV ini perlu dilakukan untuk menilai kelayakan suatu usaha yang akan dilakukan. Hal ini sesuai dengan Gittinger (1986), Net Present Value (NPV) merupakan nilai sekarang dari arus manfaat yang ditimbulkan oleh penanaman investasi. Berdasarkan kriteria NPV suatu proyek atau usaha layak untuk dilaksanakan apabila NPV lebih besar dari nol.

\section{Benefit Cost Ratio (B/C Rasio)}

Nilai Benefit Cost Ratio (B/C Rasio) merupakan perbandingan antara manfaat bersih yang telah didiskontokan yang bernilai positif dengan manfaat bersih yang telah didiskontokan yang bernilai negatif. Nilai untuk manfaat bersih terdiskonto yang bernilai negatif berada pada tahun nol. Sementara itu nilai untuk manfaat bersih terdiskonto yang bernilai positif terjadi pada periode 1 hingga periode 20. Berdasarkan hasil penelitian diperoleh nilai $\mathrm{B} / \mathrm{C}$ rasio sebesar 2,24 pada tingkat suku bunga 5,75 $\%$. Makna angka ini menjelaskan bahwa setiap tambahan pengeluaran satu rupiah dalam biaya produksi akan menghasilkan tambahan penghasilan dalam bentuk keuntungan bersih sebesar 2,24 rupiah. Berdasarkan kriteria B/C Rasio usaha Keramba Jaring Apung (KJA) di Dam Betuk layak dilakukan karena memiliki nilai $\mathrm{B} / \mathrm{C}$ rasio yang lebih besar dari satu. Hal ini sependapat dengan Kadariah (1988), yang menyatakan bahawa suatu proyek akan layak apabila B/C rasio lebih besar dari satu.

\section{Internal Rate of Return (IRR)}

Nilai IRR yang diperoleh dari hasil penelitian menunjukan bahwa nilai IRR berada pada nilai discount rate ( i1) $=30 \%$, dan pada nilai discount rate (i2) $=35 \%$. Berdasarkan hasil penelitian maka diperolah nilai IRR sebesar 31,69 \%, dengan kata lain usaha ini akan memberikan kelebihan 
SEMAH : Journal Pengelolaan Sumberdaya Perairan VOL. 2 No. 3

Desember 2018

pendapatan rata-rata setiap tahun dari modal yang telah ditanamkan sebesar 31,69 \% . Berdasarkan kriteria ini suatu usaha atau proyek dikatakan layak jika IRR lebih besar dari tingkat suku bunga. Nilai IRR pada usaha ini lebih besar dari nilai Opportunity Cost of Capital atau suku bunga sebesar $5,75 \%$. Dengan demikian, pada biaya opportunity cost of capital sebesar 5,42\%, usaha ini masih layak dilaksanakan karena memberikan pendapatan rata-rata sebesar $31,69 \%$ per tahun dari modal yang ditanamkan.

\section{Surplus Pelaku Utama Perikanan} Keramba Jaring Apung (KJA)

Besar kecilnya surplus pembudidaya ikan Keramba Jaring Apung (KJA) di Dam betuk ini tergantung dari (1) jumlah keramba yang dimiliki, (2) jumlah hasil panen dan (3) harga ikan saat panen. Adapun data surplus pembudidaya ikan pada keramba Karing Apung (KJA) di Dam Betuk dapat dilihat pada tabel 2 dibawah ini.
http://ojs.umb-bungo.ac.id/index.php/SEMAHJPSP

ISSN : 2580-0736

\section{Break Event Point (BEP) Usaha Keramba Jaring Apung (KJA) Dam Betuk Serta Laporan Laba/Rugi}

Dari hasil penelitian yang dilakukan maka di peroleh nilai break event point (BEP) untuk kegiatan budidaya Keramba Jaring Apung (KJA) adalah sebesar RP. 195.757.600. Dimana untuk mencari perhitungannya sendiri didapat dari biaya tetap, biaya variabel serta jumlah penjualan/ pendapatan. Sedangkan perhitungan laba dari kegiatan budidaya Keramba Jaring Apung (KJA) diproleh laba bersih sebanyak Rp.334.676.483,31.

\section{Kesimpulan dan saran}

1.Kesimpulan

Berdasarkan hasil penelitian yang telah dilaksanakan pada usaha budidaya ikan Keramba Jaring Apung (KJA) di Dam Betuk Kecamatan Tabir lintas Kabupaten Merangin dapat disimpulkan bahwa usaha Keramba Jaring Apung (KJA) di Dam Betuk merupakan usaha yang layak untuk

Tabel 2. Surplus Pembudidaya Ikan Keramba Jaring Apung (KJA) Dam Betuk

\begin{tabular}{ccccc}
\hline No & Uraian & $\begin{array}{c}\text { Keuntungan } \\
\text { Rendah (Rp) }\end{array}$ & $\begin{array}{c}\text { Keuntungan } \\
\text { Tinggi (Rp) }\end{array}$ & $\begin{array}{c}\text { Jumlah Rata- } \\
\text { rata (Rp) }\end{array}$ \\
\hline 1. & Jumlah penerimaan & 26.880 .000 & 57.120 .000 & 568.960 .000 \\
2. & Jumlah keutungan/Th & 3.633 .200 & 10.026 .400 & 89.520 .600 \\
3. & Jumlah keuntungan/ Skls & 1.816 .600 & 5.013 .200 & 44.760 .300 \\
4. & Surplus pembudidaya & 5.880 .000 & 15.120 .000 & 138.460 .000 \\
\hline
\end{tabular}

Sumber : Data Primer 2018

Pembudidaya ikan di Dam Betuk memasarkan hasil usaha budidaya secara langsung ke konsumen serta dengan agen penjualan. Adapun harga jual ikan ke konsumen yaitu Rp. 28.000/ kg. Sehingga dari penjualan ikan tersebutlah di peroleh surplus untuk pembudidaya ikan.

nilai NPV sebesar Rp 10.936.524, nilai B/C rasio sebesar 2,24, nilai IRR sebesar 31,69 \%, nilai BEP sebesar Rp. 195.757.600. Keuntungan rata-rata persiklus (dalam satu tahun 2 siklus) dari usaha budidaya ikan Keramba Jaring Apung (KJA) di Dam Betuk adalah Rp. 2.984.020. 
SEMAH : Journal Pengelolaan Sumberdaya Perairan VOL. 2 No. 3

Desember 2018

2.Saran

Disarankan kepada masyrakat lain yang ada disekitar lokasi Dam Betuk untuk melaksanakan kegiatan budidaya ikan sistem Keramba Jaring Apung (KJA), karena dilihat dari analisa usaha menunjukan bahwa kegiatan tersebut layak untuk dilaksanakan.

Peran serta Pemerintah dalam

memajukan sektor perikanan serta pemberdayaan petani/pembudidaya ikan sangat diharapakan terutama dalam pengelolaan Keramba Jaring Apung ( KJA) agar bisa lebih maksimal.

DAFTAR PUSTAKA

Abdulkadir,I. 2010. Keramba Jaring Apung. www.farraQafay.Maret 2017.

Badan Pelaksana Penyuluhan Pertanian Perikanan dan Kehutanan Kabupaten Merangin.2016. Programa Penyuluhan Perikanan Kecamatan Tabir Lintas Kabupaten Merangin.

Badan Pusat Statistik. 2014. Tofograpi Kabupaten Merangin. Merangin.

Djuwari. 1994. Aspek-Aspek Ekonomi dalam Usahatani. Program Pasca Sarjana. UGM. Yogyakarta

Gittinger J P. 1986. Analisa Kelayakan Proyek Pertanian. UI Press, Jakarta.

Hertati, R. 2011. Kajian Usaha Budidaya Keramba Ikan Jaring Apung Terhadap Tingkat Kesejahteraan Masyarakat di Danau Bebeko Bathin III Kabupaten Muara Bungo.

Krismono, 1995. Penataan Ruang Perairan Umum untuk Mendukung Agribisnis
http://ojs.umb-bungo.ac.id/index.php/SEMAHJPSP

ISSN : 2580-0736

dan Agroindustri. Prosiding Simposium Perikanan Indonesia I Tanggal 25-27 Agustus 1995. Jakarta.

M.Subana dan Sudrajat. 2001. Dasar-dasar Penelitian Ilmiah. Bandung. CV. Pustaka Setia 